\title{
Comparative Effects of Graded Levels of Moringa Leaf Meal on Haematological and Serum Biochemical Profile of Broiler Chickens
}

\author{
L.A Tijani ${ }^{1}$, A.M Akanji ${ }^{2}$, K. Agbalaya ${ }^{1}$ and M. Onigemo ${ }^{1}$ \\ Received : $7^{\text {th }}$ January $2016 /$ Accepted : $2^{\text {nd }}$ April 2016
}

\begin{abstract}
This study was carried out to determine the effects of Moringa oleifera leaf meal on the haematological and serum biochemical profile of broiler chickens. Fresh Moringa leaves (FML) were shade - dried for four (04) days and milled into meal. A total of two hundred (200) unsexed broiler chickens (Anak strain) with a mean body weight of $49.16 \mathrm{~g} /$ bird \pm 0.09 were allotted to five (05) treatments at forty (40) birds per each in a completely randomized design experiment. Each treatment group was further divided into five (05) replicates. Moringa oleifera leaf meal (MOLM) was incorporated into the broiler starter and finisher diets at $0 \%, 5 \%, 10 \% 15 \%$ and $20 \%$ levels respectively. The chemical composition of the MOLM showed higher values of crude protein, crude fibre, calcium, iron, tannin, phytic acid, saponin and oxalate contents than FML. The haematological profile in birds fed 5\% and 15\% MOLM showed higher $(P<0.05)$ packed cell volume than those fed 20\% MOLM. The haemoglobin values were similar $(P>0.05)$ between birds fed $5 \%, 10 \%$ and $15 \%$ MOLM - based diets, but reduced significantly $(P<0.05)$ in birds fed 20\% MOLM. The white blood cell count was significantly $(P<0.05)$ higher in birds fed $15 \%$ MOLM, while the lowest was obtained in those fed with 20\% MOLM. The serum biochemical indices in birds fed 20\% MOLM showed significant reductions $(P<0.05)$ in albumin, total protein, uric acid, aspartate amino transferase and alanine amino transferase contents. The creatinine content was significantly $(P<0.05)$ higher in birds fed 20\% MOLM -based diet. The present study concluded that MOLM can be incorporated into broiler diets at 15\% level without adverse effects on the haematological and serum biochemical indices of the broiler chickens.
\end{abstract}

Keywords: Moringa oleifera leaf meal, broilers, blood

\section{INTRODUCTION}

The poultry industry in the developing countries is facing some challenges, one of which is an increase in the cost of feed because of high prices of protein and energy sources (Abbas, 2013). Livestock feed costs in developing countries are a continuing challenge. The high and increasing prices for animal feeds have compelled researchers to direct their attention to non-conventional feed sources, with particular emphasis on protein substitutes. The use of leguminous multipurpose trees and shrubs has been suggested to be a viable alternative source of proteins, vitamins and minerals for poultry feeding. Plant leaves are commonly processed into leaf meals for use as poultry feed. Examples of the leaf meals which have been widely used in feeding non- ruminant animals include Leucaena leucocephala, Gliricidia sepium, Sesbania sesban and Manihot esculenta (Gadzirayi et al., 2012). However, Moringa (Moringa oleifera) is presently being focused globally as another promising leaf meal in livestock feeding.

Moringa is drought-tolerant and grows at a rainfall of 250-1500 mm per year (Martina, 2007). Rich in nutrients such as protein and

1 Department of Animal Production and Technology School of Agriculture, Lagos State Polytechnic, Nigeria.

2 Department of Animal Production, College of Agricultural Sciences, Olabisi Onabanjo University, Ayetoro Campus, Ogun State, Nigeria. 
minerals, Moringa is one of those plants that have not been studied for many years but now is being investigated for its fast growth, higher nutritional value, and increasing utilisation as a livestock fodder crop (Nouman et al., 2013). The feeding value of Moringa has been re-counted to be analogous to that of soybeans and rapeseed meal (Soliva et al., 2004). With the leaves of Moringa being rich in nutrients, pregnant women and lactating mothers use the powdered leaves to enhance their children's nourishment, principally in under developed countries where malnutrition is common (Stephen et al., 2008 and Sudha et al., 2010).

Haematology has been defined as the study of blood and it plays an important role in clinical pathology as well as in disease diagnostic process (Lutz and Prytulski 2008). Haematology includes not only the examination of the cellular and fluid portions of blood, but also the study of tissues that form, store and circulate blood cells.

The serum is the plasma component of blood which lacks coagulation factors. It is similar to interstitial fluid in which the correct composition of key ions acting as electrolytes is essential for normal functioning of muscles and nerves. Other components in the serum include proteins, which assist with maintaining $\mathrm{pH}$ and osmotic balance while giving viscosity to the blood; antibodies, or specialized proteins that are important for defense against viruses and bacteria; lipids, including cholesterol, which are transported in the serum; and various other substances including nutrients, hormones, metabolic waste, and external substances, such as drugs, viruses and bacteria (Martin $\left.{ }^{\mathrm{b}} ., 2007\right)$.

The result of haematology and serum analysis is usually used to assess the health status of an animal. Haematological and serum parameters have been observed as good indicators of the physiological status of animal and its changes are important in assessing the response of animal to various physiological situations (Khan and Zafar, 2005). In a work carried out by Ewuola et al., (2012) on the haematological and serum biochemical response of growing rabbits fed graded levels of MOLM, no significant difference was obtained between the aspartate amino transferase, alanine amino transferase and alkaline phosphatase activities in those fed control diet and 5\%,10\% and 15\% MOLM. Gakuya et al., (2014) fed MOLM to broiler chickens and reported reduction in the low density lipoproteins in those fed at 30\% level of inclusion.

This study was carried out to determine the effects of graded levels of Moringa oleifera leaf meal on haematological and serum biochemical profile of broiler chickens

\section{MATERIALS AND METHODS}

Fresh leaves of Moringa oleifera were harvested within the premises of the Lagos State Polytechnic and Olabisi Onabanjo University, South Western Nigeria. The harvested leaves were shade dried for four (04) days and milled in a hammer mill fitted with $2 \mathrm{~mm}$ sieve. The product here was tagged Moringa oleifera leaf meal (MOLM).

\section{Chemical analysis}

The fresh moringa leaves (FML) and MOLM were analysed for their chemical composition comprising the proximate composition, mineral contents and anti-nutritional factors (Table 01). The proximate composition and mineral contents of FML and MOLM were determined using the analytical methods described by AOAC (2012). Concentrations of tannin, phytate and oxalate in the FML and MOLM were determined using the procedural methods as outlined by Dawra et al., (1988), Maga (1983) and Apata (1990) respectively

\section{Experimental diets}

Five starter and finisher diets (Tables 02 and 03) were formulated for the birds. Moringa oleifera 
leaf meal (MOLM) was incorporated into the diets at $0 \%, 5 \%, 10 \%, 15 \%$ and $20 \%$ levels respectively. Using NRC (1994), the diets were formulated to provide $23 \%$ crude protein and $3200 \mathrm{kcal} / \mathrm{kg}$ at the starter phase; and $20 \%$ crude protein and $3000 \mathrm{kcal} / \mathrm{kg}$ at the finisher phase.
DL - methionine and lysine were added into the diets at $0.3 \%$ and $0.1 \%$ levels so as to ensure the amino acids were not limiting. The proximate composition of the diets (Tables 04 and 05) were analyzed using the analytical procedure as described by AOAC (2012)

Table 01: Chemical composition of fresh Moringa leaves and shade dried Moringa leaf meal (as fed basis)

\begin{tabular}{lccc}
\hline \multicolumn{1}{c}{ Variable } & FML $(\%)^{1}$ & MOLM $(\%)^{2}$ & $\% \Delta^{3}$ \\
\hline Dry matter(\%) & 34.9 & 93.6 & -90.0 \\
Crude protein(\%) & 6.7 & 22.6 & +70.4 \\
Crude fibre (\%) & 1.2 & 10.1 & +88.2 \\
Ether extract (\%) & 1.8 & 3.4 & +47.1 \\
Ash (\%) & 3.8 & 7.9 & +51.9 \\
Nitrogen free extract $(\%)$ & 21.4 & 49.6 & +56.6 \\
Calcium (mg/100g) & 4.21 & 6.98 & +65.79 \\
Iron (mg/100g) & 1.76 & 2.98 & +69.32 \\
Potassium (mg/100g) & 5.45 & 7.09 & +30.09 \\
Zinc (mg/100g) & 4.42 & 5.89 & +33.26 \\
Tannin (mg/100g) & 2.34 & 2.92 & +24.79 \\
Phytic acid( $\mathrm{mg} / 100 \mathrm{~g})$ & 41.34 & 42.68 & +3.24 \\
Oxalate $(\mathrm{mg} / 100 \mathrm{~g})$ & 4.48 & 5.01 & +11.83 \\
Saponin $(\%)$ & 6.41 & 6.76 & +5.46 \\
\hline
\end{tabular}

$\mathrm{FML}=$ Fresh moringa leaves; MOLM $=$ Moringa leaf meal; $\Delta=$ Change Means are from triplicate determination

Table 02: Ingredient composition of broiler starter diets

\begin{tabular}{lccccc}
\hline \multicolumn{1}{c}{ Ingredients } & Control & 5\% MOLM $^{1}$ & 10\%MOLM & 15\%MOLM $^{3}$ & 20\%MOLM $^{4}$ \\
\hline Maize & 54.90 & 56.79 & 50.79 & 49.79 & 42.60 \\
Soybean meal & 20.00 & 13.00 & 13.00 & 12.00 & 12.00 \\
Groundnut cake & 10.00 & 12.00 & 14.00 & 12.00 & 10.00 \\
Moringa leaf meal & - & 5.00 & 10.00 & 15.00 & 20.00 \\
Fish meal & 2.50 & 2.50 & 2.50 & 2.50 & 2.50 \\
Wheat offal & 4.00 & 3.00 & 2.00 & 2.00 & 3.00 \\
Brewer Dried grains & 2.70 & 3.00 & 3.00 & 1.75 & 2.00 \\
Palm oil & 1.00 & 3.00 & 3.00 & 3.00 & 3.00 \\
Bone meal & 2.00 & 2.00 & 2.00 & 2.00 & 2.00 \\
Oyster shell & 1.50 & 1.50 & 1.50 & 1.50 & 0.50 \\
Salt & 0.50 & 0.50 & 0.50 & 0.50 & 0.50 \\
Premix & 0.50 & 0.50 & 0.50 & 0.50 & 0.30 \\
Methionine & 0.30 & 0.30 & 0.30 & 0.30 & 0.10 \\
Lysine & 0.10 & 0.10 & 0.10 & 22.76 & 22.54 \\
culated Crude protein (\%) & 22.90 & 22.80 & 22.74 & 3011.70 & 3001.40 \\
Calculated Metabolizable & & & & & \\
Energy (Kcal/kg) & 3101.20 & 3104.12 & 3024.35 & & \\
\hline
\end{tabular}

MOLM= Moringa leaf meal.

Premix supplied, per kilogram of diet: vitamin A, 12,000 IU; vitamin D3, 2,000 IU; vitamin E, 50 IU; vitamin B1, $1 \mathrm{mg}$; vitamin B2, $3 \mathrm{mg}$; vitamin B6, $1 \mathrm{mg}$; vitamin B12, $10 \mu \mathrm{g}$; vitamin $\mathrm{K}, 2 \mathrm{mg}$; copper (cupric sulphate), $75 \mathrm{mg}$; nicotinic acid, $12 \mathrm{mg}$; pantothenic acid, $10 \mathrm{mg}$; iron, $200 \mathrm{mg}$; cobalt, $0.5 \mathrm{mg}$; manganese, 40mg; zinc, $90 \mathrm{mg}$, iodine, $1 \mathrm{mg}$; selenium, $0.2 \mathrm{mg}$; calcium, $31.25 \mathrm{~g}$; sodium, $10 \mathrm{~g}$ 
Table 03: Ingredient composition of broiler finisher diets

\begin{tabular}{lccccc}
\hline \multicolumn{1}{c}{ Ingredients } & Control & $5 \%$ MOLM $^{1}$ & $10 \%$ MOLM $^{2}$ & $15 \%$ MOLM $^{3}$ & $20 \%$ MOLM $^{4}$ \\
\hline Maize & 59.90 & 61.79 & 55.79 & 53.79 & 46.60 \\
Soybean meal & 15.00 & 8.00 & 8.00 & 8.00 & 8.00 \\
Groundnut cake & 10.00 & 12.00 & 14.00 & 12.00 & 10.00 \\
Moringa leaf meal & - & 5.00 & 10.00 & 15.00 & 20.00 \\
Fish meal & 2.50 & 2.50 & 2.50 & 2.50 & 2.50 \\
Wheat offal & 4.00 & 3.00 & 2.00 & 2.00 & 3.00 \\
Brewer Dried grains & 2.70 & 3.00 & 3.00 & 1.75 & 2.00 \\
Palm oil & 1.00 & 3.00 & 3.00 & 3.00 & 3.00 \\
Bone meal & 2.00 & 2.00 & 2.00 & 2.00 & 2.00 \\
Oyster shell & 1.50 & 1.50 & 1.50 & 1.50 & 1.50 \\
Salt & 0.50 & 0.50 & 0.50 & 0.50 & 0.50 \\
Premix & 0.50 & 0.50 & 0.50 & 0.50 & 0.50 \\
Methionine & 0.30 & 0.30 & 0.30 & 0.30 & 0.30 \\
Lysine & 0.10 & 0.1 & 0.1 & 0.1 & 0.1 \\
Crude protein (\%) & 20.01 & 19.97 & 19.89 & 19.86 & 19.87 \\
Metabolizable Energy (Kcal $/ \mathrm{kg})$ & 2989.11 & 2987.16 & 2911.43 & 2904.37 & 2901.41 \\
\hline
\end{tabular}

MOLM= Moringa leaf meal

Premix supplied, per kilogram of diet: vitamin A, 12,000 IU; vitamin D3, 2,000 IU; vitamin E, 50 IU; vitamin B1, $1 \mathrm{mg}$; vitamin B2, $3 \mathrm{mg}$; vitamin B6, $1 \mathrm{mg}$; vitamin B12, 10 gg; vitamin $\mathrm{K}, 2 \mathrm{mg}$; copper (cupric sulphate), $75 \mathrm{mg}$; nicotinic acid, $12 \mathrm{mg}$; pantothenic acid, $10 \mathrm{mg}$; iron, $200 \mathrm{mg}$; cobalt, $0.5 \mathrm{mg}$; manganese, $40 \mathrm{mg}$; zinc, $90 \mathrm{mg}$, iodine, $1 \mathrm{mg}$; selenium, $0.2 \mathrm{mg}$; calcium, $31.25 \mathrm{~g}$; sodium, $10 \mathrm{~g}$

Table 04: Analysed chemical composition of broiler starter diets

\begin{tabular}{lccccc}
\hline & Control & 5\% MOLM $^{1}$ & 10\%MOLM $^{2}$ & 15\%MOLM $^{3}$ & 20\%MOLM $^{4}$ \\
\hline Dry matter(\%) & 96.32 & 94.23 & 94.15 & 93.87 & 93.76 \\
Crude protein(\%) & 22.97 & 22.64 & 22.51 & 22.37 & 22.14 \\
Crude fibre(\%) & 4.32 & 4.56 & 5.06 & 5.32 & 5.67 \\
Ether extract (\%) & 3.84 & 3.32 & 3.34 & 3.23 & 3.14 \\
Ash (\%) & 6.98 & 7.01 & 7.87 & 8.05 & 8.17 \\
Nitrogen free extract (\%) & 58.21 & 56.70 & 55.37 & 54.90 & 54.64 \\
Calcium (\%) & 1.01 & 1.14 & 1.26 & 1.31 & 1.41 \\
Phosphorus(\%) & 0.52 & 0.54 & 0.59 & 0.64 & 0.69 \\
\hline
\end{tabular}

Table 05: Analysed chemical composition of broiler finisher diets

\begin{tabular}{lccccc}
\hline & Control & 5\% MOLM $^{1}$ & 10\%MOLM $^{2}$ & 15\%MOLM $^{3}$ & 20\%MOLM $^{4}$ \\
\hline Dry matter(\%) & 96.56 & 94.47 & 94.23 & 93.51 & 93.42 \\
Crude protein(\%) & 19.89 & 19.63 & 19.43 & 19.21 & 19.01 \\
Crude fibre(\%) & 4.17 & 4.43 & 5.19 & 5.24 & 5.54 \\
Ether extract (\%) & 3.72 & 3.14 & 3.08 & 3.04 & 3.05 \\
Ash (\%) & 6.53 & 6.91 & 7.86 & 8.01 & 8.11 \\
Nitrogen free extract(\%) & 62.25 & 60.36 & 58.67 & 58.01 & 57.71 \\
Calcium (\%) & 0.83 & 0.89 & 0.95 & 1.03 & 1.21 \\
Phosphorus(\%) & 0.49 & 0.51 & 0.51 & 0.63 & 0.65 \\
\hline
\end{tabular}




\section{Experimental birds}

Two hundred (200) day-old unsexed broiler chicks (Anak strain) of average body weight of $49.16 \mathrm{~g} / \mathrm{bird} \pm 0.09$ were randomly distributed into five (05) dietary treatment groups. Each group consisting of forty (40) chicks was replicated five times in a completely randomized design. Feed and water was supplied adlibitumly, and uniform lighting was provided 24 hourly. All the birds were vaccinated against to Newcastle disease on day $28^{\text {th }}$ and the vaccination against to infectious bursal disease was done on the day $10^{\text {th }}$ and $35^{\text {th }}$. Also, the birds were administered with medication against to round worms on day $39^{\text {th }}$. Between day $41^{\text {st }}$ and $47^{\text {th }}$, the birds were administered with medication against to coccidiosis. The starter phase of the experiment was between the $1^{\text {st }}$ and $5^{\text {th }}$ week. The finisher phase was between the $6^{\text {th }}$ and the $8^{\text {th }}$ week.

The experiment was performed in accordance with the ethical guidelines and regulations of the Olabisi Onabanjo University, Ogun state, Nigeria, and in accordance with the internationally accepted principles for laboratory animal use and care

\section{Analytical measurements}

On the $7^{\text {th }}$ and $8^{\text {th }}$ week of the experiment, blood samples $(2 \mathrm{ml}$ of blood for serum biochemical tests and $1 \mathrm{ml}$ of blood in vials with $2 \mathrm{mg}$ ethylene-diamine tetra-acetic acid (EDTA) for haematology) were collected from the brachial vein of the birds (fifteen birds per treatment group). The Red Blood Cell (RBC), total White Blood Cell (WBC), haemoglobin (HB), Packed Cell Volume (PCV), monocytes and neutrophils counts were determined as described by Ewuola and Egbunike (2008). The mean corpuscular haemoglobin $(\mathrm{MCH})$ and mean corpuscular volume (MCV) were determined using appropriate formulae as described by Emiola et al., (2013). Serum creatinine, alanine amino transferase, aspartate amino transferase, uric acid total protein and albumin were determined using methods described by Bahman et al., (2011)

\section{Statistical analysis}

All data collected were analysed using analysis of variance (ANOVA). Differences in means were separated using Duncan Multiple Range Test. All statistics analyses were done using the Assistat - Assistance Statistical software developed by Silva and Azevedo, (2009).

\section{RESULTS AND DISCUSSION}

The chemical composition of the fresh Moringa leaves (FML) and Moringa oleifera leaf meal (MOLM) are presented in Table 01. Dry matter content was higher in the MOLM. Analysed crude protein, crude fibre, ash, calcium, potassium, zinc, iron, tannin, oxalate saponin and phytic acid contents were higher in MOLM than the FML. The data obtained based on the chemical composition of the MOLM are similar to the findings of Aye and Adegun (2013). The higher dry matter content in the MOLM can be attributed to the loss of moisture content during processing. This is consistent with earlier reports of Mbah et al., (2012) who processed Moringa leaves through sun-drying and shade drying methods. The crude protein content in the FML agrees with the findings of Gadzirayi et al., (2012). The higher crude protein content in the MOLM is similar to reports of Mbah et al., (2012) on shade - dried Moringa leaves. However, the crude protein content in the MOLM is lower than the amount obtained in the Moringa seeds as reported by Moreki and Gabanakgosi, (2014). The calcium, iron, potassium and zinc contents in the FML are similar to the reports of Aye and Adegun (2013). The anti-nutritional factors in the FML and MOLM agree with other reports which indicated the presence of tannins, phenols, alkaloids, phytin and mimosine in Leucaena, Moringa and Gliricidia (Gadzirayi et al.,2012). 
Results obtained on the haematological profile of the birds are shown in Table 06. Higher $(\mathrm{P}<0.05)$ values for packed cell volume (PCV) were obtained in birds fed 5\% and 15\% MOLM with significant $(\mathrm{P}<0.05)$ reduction in those fed $20 \%$ MOLM. The haemoglobin $(\mathrm{Hb})$ values were similar $(\mathrm{P}>0.05)$ between birds fed 5\%, $10 \%$ and $15 \%$ MOLM based diets, but reduced in those fed 20\% MOLM. White blood cell count (WBC) was significantly $(\mathrm{P}<0.05)$ higher in birds fed $15 \%$ MOLM, but reduced $(\mathrm{P}<0.05)$ in those fed 20\% MOLM based diet. The red blood cells (RBC) and the monocytes count were not significantly $(\mathrm{P}>0.05)$ different across the groups of birds. The neutrophils count were significantly $(\mathrm{P}<0.05)$ higher in birds fed $15 \%$ MOLM, but least in those fed the control diet. The mean corpuscular volume (MCV) was significantly $(\mathrm{P}<0.05)$ increased in birds fed $10 \%$ and $15 \%$ MOLM , but reduced in birds fed $5 \%$ and $20 \%$ MOLM. The mean corpuscular haemoglobin $(\mathrm{MCH})$ was reduced in birds fed $5 \%$ and 20\% MOLM based diets respectively. The reduction in the $\mathrm{PVC}, \mathrm{Hb}, \mathrm{RBC}, \mathrm{WBC}$ and neutrophils in birds fed 20\% MOLM can probably be due to the combined effects of residual anti nutritional factors. According Lutz and Prytulski (2008) iron is essential for haemoglobin formation, and studies have shown that phytate and oxalate are inhibitory to iron absorption (Davies and Nitingale, 1975; Apata, 1990). The reduction in the $\mathrm{Hb}$ of the birds fed $20 \%$ can attributed specifically to higher intake of phytate and oxalate. Tannin has also been reported to decrease protein digestibility which in turn has deleterious effects on $\mathrm{RBC}$ and $\mathrm{Hb}$ in chickens (Emiola et al., 2003).In a similar study, increasing inclusion levels of Moringa leaf meal was found to reduce the haematological indices in rats (Odetola et al., 2012). Studies have shown positive correlations between tannin, phytate and oxalate intakes and $\mathrm{Hb}$ and $\mathrm{RBC}$ in adult cockerels and broiler chickens fed raw jackbeans and bambara groundunts respectively (Akanji, 2002). Apata and Ologhobo (1989) reported that dietary phytic acid depressed the bioavailability iron from legume seeds in rats.

The effect of different MOLM inclusion levels on the serum biochemical indices are shown in Table 07. The serum albumin content was significantly $(\mathrm{P}<0.05)$ higher in birds fed control diet than those fed 5\%,10\% and $15 \%$ MOLM.Serum total protein contents were similar $(\mathrm{P}>0.05)$ between birds fed control diet and $15 \%$ MOLM, but significantly $(\mathrm{P}<0.05)$ lowered in those fed 20\% MOLM. Uric acid contents were similar $(\mathrm{P}>0.05)$ in birds fed $5 \%$, $10 \%$ and $15 \%$ MOLM - based diets. The uric acid content was significantly $(\mathrm{P}<0.05)$ higher in birds fed 20\% MOLM. The aspartate amino transferase and alanine amino transferase contents were statistically $(\mathrm{P}>0.05)$ similar between birds fed control diet and 5\% MOLMbased diet, but significantly $(\mathrm{P}<0.05)$ lowered in those fed 20\% MOLM The creatinine content was significantly $(\mathrm{P}<0.05)$ higher in birds fed 20\% MOLM - based diet. The depressive effect of the MOLM at the $20 \%$ inclusion level could be attributed to the adverse influence of the Moringa phytotoxins such as lecithin, moringin, moringinine, glucosinolates, tannins, nitrite, oxalate and phytate (Odetola, 2012). These observations are similar to the findings of Vastana and Daramola (2014) who investigated the effects of MOLM on haematological parameters and cholesterol content in rabbits. Consumption of MOLM in the diets at varying levels increased the concentration or amounts of creatinine and uric acid in the birds fed $20 \%$ MOLM. Elevated levels of creatinine and uric acid in response to increasing quantity of the leaf meal indicated that the fed animals had problem with the quality of the protein in the test feedstuff. In a study to test the effects of anti- nutritional factors on broiler chickens fed raw jack beans, D'Mello (1991) reported that increased intake of canavanine led to inhibition of transamidinase activity and creatinine synthesis which subsequently reduced growth and feed conversion efficiency in the birds. 
Table 06: Haematological profile of broilers (8weeks old) fed Moringa leaf meal (MOLM)

\begin{tabular}{|c|c|c|c|c|c|c|}
\hline \multirow{2}{*}{ Variable } & \multirow[b]{2}{*}{ Control } & \multirow[b]{2}{*}{$5 \% \mathrm{MOLM}^{1}$} & \multicolumn{3}{|c|}{ Diets } & \multirow[b]{2}{*}{ SEM } \\
\hline & & & $10 \% \mathrm{MOLM}^{2}$ & $15 \% \mathrm{MOLM}^{3}$ & $20 \% \mathrm{MOLM}^{4}$ & \\
\hline $\operatorname{PCV}(\%)$ & $25.00^{\mathrm{a}}$ & $24.00^{\mathrm{ab}}$ & $21.00^{\mathrm{c}}$ & $23.00^{\mathrm{b}}$ & $16.67^{\mathrm{d}}$ & 2.31 \\
\hline $\mathrm{HB}(\mathrm{g} / \mathrm{dl})$ & $8.30^{\mathrm{a}}$ & $7.97^{\mathrm{ab}}$ & $7.00^{\mathrm{b}}$ & $7.63^{\mathrm{b}}$ & $5.53^{\mathrm{c}}$ & 0.78 \\
\hline WBC (x109/1) & $2.35^{\mathrm{a}}$ & $2.22^{b}$ & $2.25^{\mathrm{b}}$ & $2.37^{\mathrm{a}}$ & $2.09^{c}$ & 0.16 \\
\hline MONOCYTE COUNT & 0.33 & 0.33 & 0.67 & 0.33 & 0.00 & 0.11 \\
\hline NEUTROPHILS COUNT & $24.00^{\mathrm{b}}$ & $28.67^{\mathrm{ab}}$ & $29.33^{\mathrm{ab}}$ & $33.33^{\mathrm{a}}$ & $30.33^{\mathrm{a}}$ & 1.74 \\
\hline $\mathrm{RBC}\left(\times 10^{12} / 1\right)$ & 3.94 & 3.76 & 3.65 & 3.81 & 3.07 & 0.15 \\
\hline $\mathrm{MCV}$ & $4.99^{b}$ & $2.74^{\mathrm{d}}$ & $5.87^{\mathrm{a}}$ & $5.42^{\mathrm{ab}}$ & $3.98^{\mathrm{c}}$ & 0.85 \\
\hline $\mathrm{MCH}$ & $1.65^{b}$ & $0.91^{\mathrm{d}}$ & $1.96^{\mathrm{a}}$ & $1.80^{\mathrm{ab}}$ & $1.32^{c}$ & 0.62 \\
\hline
\end{tabular}

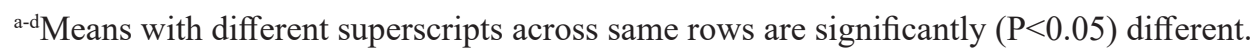

$\mathrm{PCV}=$ Packed cell volume; $\mathrm{HB}=$ Haemoglobin $; \mathrm{RBC}=$ Red blood cell; $\mathrm{WBC}=$ White blood cell; $\mathrm{MCV}=\mathrm{Mean}$ corpuscular volume, $\mathrm{MCH}=$ Mean corpuscular haemoglobin

Table 07: Serum biochemical profile of broilers fed with Moringa leaf meal (MOLM)

\begin{tabular}{lcccccc}
\hline \multicolumn{1}{c}{ Variable } & \multicolumn{5}{c}{ Diets } \\
\cline { 2 - 6 } & Control & $5 \%$ MOLM $^{1}$ & $10 \%$ MOLM $^{2}$ & $15 \%$ MOLM $^{3}$ & $20 \%$ MOLM $^{4}$ & SEM \\
\hline Albumin (mmol/l) & $26.39^{\mathrm{a}}$ & $24.23^{\mathrm{b}}$ & $24.63^{\mathrm{b}}$ & $23.10^{\mathrm{b}}$ & $20.27^{\mathrm{c}}$ & 1.95 \\
Protein $(\mathrm{mmol} / \mathrm{l})$ & $43.05^{\mathrm{a}}$ & $41.58^{\mathrm{b}}$ & $41.79^{\mathrm{b}}$ & $42.09^{\mathrm{ab}}$ & $38.74^{\mathrm{c}}$ & 1.51 \\
Uric acid (mmol/1) & $4.15^{\mathrm{c}}$ & $5.28^{\mathrm{b}}$ & $5.83^{\mathrm{b}}$ & $5.21^{\mathrm{b}}$ & $7.48^{\mathrm{a}}$ & 0.52 \\
$\begin{array}{l}\text { Aspartate amino } \\
\text { transferase (iu/l) }\end{array}$ & $143.1^{\mathrm{a}}$ & $142.98^{\mathrm{a}}$ & $139.86^{\mathrm{b}}$ & $137.64^{\mathrm{b}}$ & $98.17^{\mathrm{c}}$ & 12.28 \\
$\begin{array}{l}\text { Alanine amino } \\
\text { transferase (iu/i) }\end{array}$ & $286.30^{\mathrm{a}}$ & $284.67^{\mathrm{a}}$ & $276.35^{\mathrm{b}}$ & $252.63^{\mathrm{c}}$ & $198.22^{\mathrm{d}}$ & 19.21 \\
Creatinine $(\mathrm{mmol} / \mathrm{l})$ & $71.00^{\mathrm{d}}$ & $73.40^{\mathrm{d}}$ & $79.45^{\mathrm{c}}$ & $82.56^{\mathrm{b}}$ & $120.41^{\mathrm{a}}$ & 9.13 \\
\hline
\end{tabular}

${ }^{\mathrm{a}-\mathrm{d} M e a n s}$ with different superscripts across same rows are significantly $(\mathrm{P}<0.05)$ different

\section{CONCLUSION}

From the results obtained in this study, it is concluded that the higher the inclusion level of MOLM in diets of broiler chickens the more the adverse effects on the haematological and serum biochemical profile. However, at $15 \%$ inclusion level of MOLM in the broiler diet, high values of haemoglobin, red blood cells, packed cell volume serum albumin and total protein were obtained, beyond the $15 \%$ level of inclusion of MOLM, haematological and serum biochemical indices were reduced, thus implying the maximized effects of the toxic factors. Hence, it is recommended that MOLM can be incorporated into the diets of broiler chickens up to $15 \%$ level.

\section{ACKNOWLEDGEMENTS}

The contributory roles of the laboratory staff of the Olabisi Onabanjo University, College of Agricultural Sciences, Nigeria, in the course of this research work is acknowledged. 


\section{REFERENCES}

Abbas, T.E. (2013). The use of Moringa oleifera in poultry diets. Turkish Journal of Veterinary and Animal Science. 37: pp 492-496 http://dx.doi.org/10.3906/vet-1211-40

Akanji, A.M. (2002) Enhancing the utilization of some Tropical legume seeds in diets Of Exotic chickens. Ph.D Thesis. University of Ibadan

Apata, D.F and Ologhobo,A.D (1989). Influence of phytic acid on the availability of minerals from selected tropical legume seeds. Nigerian Journal of Science. 23, pp 43-50

Apata, D. F. (1990)-0: Biochemical, Nutritional and Toxicological assessment of some tropical seeds Ph.D. Thesis, University of Ibadan, Nigeria.

Aye, P.A and Adegun, M.K. (2013). Chemical composition and some functional properties of moringa, leaucaena and gliricidia leaf meals. Agriculture and Biology Journal of North America 4(1) pp 71-77. http://dx.doi.org/10.5251/abjna.2013.4.1.71.77

Bahman, A.H. Alireza T and Siamak A. R. (2011) Comparative Study on Blood Profiles of Indigenous and Ross-308 Broiler Breeders Global Veterinaria 7 (3): pp 238-241.

Davies, N.T. and Nitingale R. (1975). The effect of phytate on intestinal absorption and mineral secretion of zinc and whole body retention of zinc, copper, iron and manganese in rats. British Journal of Nutrition 34: pp 343-351. http://dx.doi.org/10.1017/S0007114575000293

Dawra, RK, Makkar H.S.P, Singh B (1988). Protein binding capacity of microquantities of Tannins. Anal. Biochem. 170: pp 50-53. http://dx.doi.org/10.1016/0003-2697(88)90088-7

D’Mello J.P.F (1991). Toxic amino acids. In: Toxic substances in crop plants. The Royal Society of Chemistry. New York. http://dx.doi.org/10.1533/9781845698454.21

Emiola, IA., Ologhobo, A.D, Adedeji, T.A, Oladunjoye, I.O, Akanji, AM (2003). Performance characteristic of broiler chicks fed kidney beans as replacement for two conventional legumes. Moor Journal of Agricultural Research 4: pp 236-241.

Emiola, I. A., Ojediran, T. K. and Ajayi J. A. (2013) Biochemical and Heamatological Indices of Broiler Chickens fed Differently Processed Legume Seed Meals International Journal of Applied Agricultural and Apicultural Research 9 (1\&2): pp 140-149

Ewuola, E.O and Egbunike G.N. (2008). Haematological and serum biochemical response of growing rabbits bucks fed different levels of dietary fumonisin African Journal of Biotechnology, 7, pp 4304-4309

Ewuola, E.O., Jimoh O.A., Atuma O.V., Soipe O.D. (2012) haematological and serum biochemical response of growing rabbits fed graded levels of Moringa oleifera leaf meal. $10^{\text {th }}$ Proceedings of the World Rabbit Congress -Sharm El- Sheikh -Egypt, pp 679 - 683

Gadzirayi, C.T.,Masamha, B., Mupangwa, J.F.and Washaya S. (2012) Performance of Broiler Chickens Fed on Mature Moringa oleifera Leaf Meal as a Protein Supplement to Soyabean Meal. International Journal of Poultry Science 11 (1): pp 5-10. http://dx.doi.org/10.3923/ ijps.2012.5.10 
Gakuya, D.W, Mbugua, P.N Kavoi B. and Kiama S.G. (2014) Effect of supplementation of Moringa oleifera leaf meal in broiler chicken feed. International Journal of Poultry Science 13 (4): pp 208-213. http://dx.doi.org/10.3923/ijps.2014.208.213

Khan, TA, and Zafar F. (2005) Haematological study in response to varying doses of estrogen in broiler chicken. International Journal of Poultry Science.10: pp 748-751.

Lutz, C. and Prytulski K. (2008) .Nutrition and Diets Therapy. $4^{\text {th }}$ Ed jaypee Brothers Medical publishers Delhi

Maga JA (1983). Phytate: Its chemistry, occurrence, food interaction, nutritional significance and methods of analysis. Journal of Agriculture, Food and Chemistry. 30: pp 1-9. http://dx.doi. org/10.1021/jf00109a001

Martina, L.P. (2007). The moringa tree. Echo. North Fort Myers, FL 33917, USA. Available at: http://www.echonet.org

Martin , E.A. (2007). Concise Medical Dictionary (7th Ed) Oxford, England, Oxford University Press

Mbah, B.O, Eme P.E and. Paul A.E (2012) Effect of Drying Techniques on the Proximate and Other Nutrient Composition of Moringa oleifera Leaves fromTwo Areas in Eastern.Nigeria. Pakistan Journal of Nutrition 11 (11): pp 1044-1048,

Moreki, J.C. and Gabanakgosi, K (2014) Potential use of Moringa oleifera in poutry diets. Global Journal of Animal Scientific Research 2 (2) pp 109-115

Nouman, W. Basra, S.M.A, Siddiqui, M.T. Yasmeen, A, Gull T. and Alcayde. M.A.C. (2013). Potential of Moringa oleifera L. as livestock fodder crop: a review. Turkish Journal of Agriculture and Forestry. 37(1) pp 1-14.

NRC (1994). National Research Council. Nutrient requirement for poultry $9^{\text {th }}$ Edition.

Odetola, O.M., Adetola, O.O. Ijadumola T.T. Adedeji O.Y and Adu O.A. (2012). Utilization of Moringa leaf meal as a replacement for soya bean meal in rabbit's diets. Journal of Agricultural Science 2 (12) pp 309-313

Soliva, C.R, Kreuzer, M, Foidl,N, Foidl, G., Mach- Müller A and. Hess, H.D (2004) Feeding Value of Whole and Extracted Moringa oleifera Leaves for Ruminants and Their Effects on Ruminal. Animal Feed Science and Technology, 118, (1). pp 47-62.

Silva F. and Azevedo C.A.V (2009). Principlal components analysis in the software Assistant Statistical Attendance. In: World Congress on Computers in Agriculture. American Society of Agricultural and Biological Engineers.

Sudha, P. Asdaq, S. M. Dhamingi S. S and. Chan- drakala, G. K (2010) Immuno-Modulatory Activity of Methanolic Leaf Extract of Moringa oleifera in Animals, Indian Journal of Physiology and Pharmacology, Vol. 54, No. 2, pp. 133-140.

Stephen, K., Bangert, M. A. William, J Marshall A. and. William, L (2008) Clinical Biochemistry Metabolic and Clinical Aspects, Elsevier, Philadelphia. 
Vantsawa P. A. and Daramola A. (2014) .The effect of Moringa oleifera leaf meal (molm) on the hematological parameters and the cholesterol level of rabbits. American Journal of Biological, Chemical and Pharmaceutical Sciences. 2, (3) pp 1-6 